\title{
THE FIRST MOSQUE: CALEDON STREET, UITENHAGE
}

\author{
Schalk le Roux \\ Department of Architecture, University of Pretoria, Pretoria 0002 \\ PO Box 1357 Gordon's Bay 7151
}

\section{Die eerste moskee: Caledonstraat, Uitenhage}

Op 5 Maart 1849 skryf aartsdeken N.J. Merriman (1809-1882) op een van sy eerste togte om met sy nuwe parogie in die Oos-Kaap vertroud te raak, dat 'n klompie Maleiers hulle in Port Elizabeth en Uitenhage bevind het. Van hulle het eersame posisies in Algoabaai beklee en hulle het ook 'n moskee in Uitenhage gehad - die enigste in die kolonie.

Merriman was in albei gevalle verkeerd. Teen 1849 was veel meer as 'n paar "Maleiers" in die Oos-Kaap woonagtig en die moskee in Uitenhage was nie die enigste een in die kolonie nie. Wat sy opmerking belangrik maak is dat dit die eerste verwysing na 'n gevestigde Moslemgemeenskap en 'n voltooide plek vir aanbidding in daardie deel van die land is.

Oor die moskees in Kaapstad en omgewing is sedert 1970 heelwat navorsing gedoen en etlike publikasies het die lig gesien, waarvan die sleutelbronne die werke van Achmat Davids en Frank Bradlow \& Margaret Cairns is. Wat die toestand in die res van die Kaapkolonie was, is minder bekend en gepubliseerde bronne is nie geredelik beskikbaar nie.

In hierdie artikel word gekyk na beskikbare bronne om die geskiedenis na te loop. Die toestande in die destydse Uitenhage word kortliks beskryf en die koms van die eerste Moslems en die stigter van dié geloof in Uitenhage word uitgelig. Hierna word gepoog om die moskee aan die hand van konstruksiegetuienis te rekonstrueer en onbeantwoorde vrae word geïdentifiseer.

Sleutelwoorde: Maleise korps, moskee, Moslem, Oorlog van die Byl, Oos-Kaap, slaaf, Uitenhage

[There are] a few Malays at Port Elizabeth and Uitenhage. A few [are] in respectable situations at the Bay; [they] have a mosque at Uitenhage, the only one in the colony. ${ }^{1}$

Thus wrote Archdeacon N.J. Merriman (1809-1882) on 5 March 1849 during one of his first trips to acquaint himself with his new parish in the Eastern Cape, where he would eventually become archbishop.

D.H. Varley \& H. M. Matthew (eds.), The Cape Journals of archdeacon Merriman 1848-1855 (Cape Town, 1957), pp. 32-33. 
Merriman was wrong on both counts. By 1849, there were far more than only a few "Malays" in the Eastern Cape and the mosque in Uitenhage was not the only one in the colony. ${ }^{2}$ What makes his remark important is the fact that it is the first reference to a settled Muslim community and a completed place of prayer in this part of the country.

Since 1970, much research has been done on the mosques in Cape Town and vicinity and a number of publications have seen the light, among which the key sources are works of Achmat Davids and Frank Bradlow \& Margaret Cairns. ${ }^{3}$ What the situation was in the rest of the Cape Colony is less well known and published sources are not readily available.

In this article available sources to trace the history are reconsidered. Conditions in the Uitenhage of that time are described briefly and the arrival of the first Muslims and the founder of the faith in Uitenhage are highlighted. Then an effort is made to reconstruct the mosque with the aid of construction evidence and unanswered questions are identified. ${ }^{4}$

Key words: Eastern Cape, Malay corps, mosque, Muslim, slave, Uitenhage, War of the Axe

\section{Sources and arguments around origins}

Except in cases where Muslims and their building works are briefly mentioned in anniversary town publications, until the 1980s hardly anything was written about Islam in the Eastern Cape. A single exception was S.A. Rochlin's article, Origins of Islam in the Eastern Cape, which appeared in 1956. It is an important article with many pointers for further research and to which we shall return.

References to Muslims appeared in one or two short articles in the magazines of the Historical Society of Port Elizabeth. The Grace Street mosque was discussed briefly in 1961 and in 1979 the same author referred to specific stands which, by 1821 , belonged to a successful early Muslim, Fortuin Weis. ${ }^{5}$

In 1987, the Grace Street Mosque in Port Elizabeth published Muslim heritage and ancestry Port Elizabeth and Uitenhage. It was edited by A.G. Abrahams, who had close ties with the history of the mosques in both places. In this, the oral history was recorded and a number of sources were included. As regards the history of the arrival of the first Muslims, he

By the 1840s, Muslim and Malay were almost synonymous in the vernacular; however, not every Malay referred to in texts can necessarily be regarded as Muslim. Purvis, J. (ed.), Letters from the Cape by Lady Duff Gordon (London, 1921 [1864]), p. 31.

A. Davids, The Mosques of Bo-Kaap (Clareinch, 1980); F. Bradlow \& M. Cairns, The Early Cape Muslims (Cape Town, 1978).

Die Masjid Al-Qudama, in Caledon Street, Uitenhage is generally known as the Caledon Street mosque, also in documents and on the latest building plans in 1986.

"Khitab" (Porter, L.), Grace Street mosque, Looking Back 1(3), 1961, p. 12; "Khitab” (Porter, L.), The Malays of PE, Looking Back 19, p. 57. Thanks to Margaret Harradine for information regarding the author. 
relies on S.A. Rochlin and W.S.J. Sellick, but some of their statements need further study and historical verification. It does provide the most complete history of the mosques, their imams and the communities that has been published to date.

Another source is that of Agherdien, George and Hendricks, South End [as we knew it], edited and annotated by Roy du Pré, which was published ten years later and offered a particularly good visual image of the shattered neighbourhood in Port Elizabeth. ${ }^{6}$

Otto Terblanche merely touched on the history in a commemorative edition at the second centenary of Uitenhage in 2004, but presents the already familiar information without further reference.

The dearth of sources on Islam in the Eastern Cape is emphasised by their absence in Mohammed Haron's valuable bibliography, Muslims in South Africa. Only Abrahams, Rochlin and an article in Looking Back are listed. ${ }^{8}$

Published information is meagre and repetitive. Any research in this field therefore relies heavily on the communal memory that can be tested for acceptance by means of hitherto unused documents. An effort to do this is made below.

Since 1800 , there have been various references to the possibility that Muslims had already settled in the Eastern Cape. In what may be the first study dealing with Islam in the Eastern Cape, Rochlin mentioned the following possibilities, which are discussed briefly:

\section{Origin}

The arguments of John Barrow (1764-1848), public servant and traveller, that the inhabitants of the south-east coast had been in contact with Arabian Muslims long before the first European sailed around the southern tip of Africa, and that they probably were of shared origin was already disputed by the physician and naturalist, Hinrich Lichtenstein (17801857). ${ }^{9}$ Should there be any connection between the two, said he, it should be traced back to pre-Islamic times.

\footnotetext{
Y. Agherdien, A. C. George \& S. Hendricks, (R. H. Du Pré, ed.), South End [as we knew it] (Saltville, 1997). O. Terblanche (ed.), Uitenhage the golden town (Port Elizabeth, 2004).

M. Haron, Muslims in South Africa, an annotated bibliography (Cape Town, 1997). This is the most comprehensive bibliography to date. It supersedes earlier bibliographies by Hampson (1964), Lübbe (1985) and his own earlier works.

J. Barrow, An account of travels into the interior of Southern Africa in the years 1797 and 1798 (London, 1801), vol. 1, pp. 211-212; vol. 2 (1804), p. 117; H. Lichtenstein, Travels in Southern Africa, in the years 1803, 1804, 1805 and 1806 (Cape Town, 1928 [1812]), pp. 302-304.
} 


\section{The shipwreck of the Grosvenor}

Rochlin seeks a second possibility of early contact between Muslim and Xhosa in the presence of castaways along the coast. He refers to the lascars (here meant Indian sailors) and servants on board the Grosvenor that ran aground near the estuary of the Tezani River on 4 August 1782. ${ }^{10}$ However, among all the names, there are only two that could be of Arabian origin. About Frank Masoon nothing is known except his name and even this is not certain because some of the names in the various reports were spelled in different ways. "Hoakim [Hakim?] or Alien, Mrs. Hosea's Indian maid", was one of those who were saved together with Betty, maid to Mrs. (Lydia) Logie and seven lascars. They reached Swellendam by the end of March $1873 .{ }^{11}$ If Hoakim and some of the lascars were Muslims ${ }^{12}$, their religious influence in the six months they spent along the coast could not have been of much significance. ${ }^{13}$

A much more interesting figure in the story of the Grosvenor is that of the "Malay" who was regarded as a Dutchman by some of the castaways, "...a man lighter coloured than the natives, with straight hair." He spoke Dutch with John Sussman, "and told them that the Cape was a great way off; and, being desired to guide them, said he could not, as he was afraid of being killed if he went into the Christian country." 14

William Hubberley, servant of the second mate, Mr. William Shaw, wrote in his report on the shipwreck: "We supposed him to be a Malay that had run away from the Dutch, he speaking the language very well" and Betty testified that she (and Hoakim?) "had been living with a Malay who had left the Dutch, and all of the Lascars were found residing with such kind of people, who supported themselves on shell-fish, the natives not suffering them to reside near them." 15

S.A. Rochlin, Origins of Islam in the Eastern Cape, Africana Notes and News 12(1), 1956, pp. 21-25.

P.R. Kirby, A source book on the wreck of the Grosvenor (Cape Town, 1953), pp. 40, 46, 126, 145, 200. On p. 39, Betty was wrongly recorded as the maid of Mrs. Hosea. The name Bastiano Nardeen that can be read as Nardin appears to be misspelt. He was an Italian named Sebastiano Nardini, p. 199. This word has represented various meanings through the centuries. Taken from Urdu by the Portuguese and used to describe the lower classes in military service, by the 18th century it was used to refer to Indian sailors on British ships. They were usually Muslims. A. Ridgway (ed.), Everyman's Encyclopaedia 8 (London, 1950). In Arabic Al-Asker refers to the army. K. Ellis, et al. (eds.), American Heritage Dictionary (Boston, 1993).

Their tribulation was not at an end. They were repatriated to India on board the Microbar that ran aground on the rocks near the estuary of the Ratel River, a day after departure on 10 July 1783. Jacob van Reenen was later fined because he had plundered this wreck. P.R. Kirby, Van Reenen, Jacob, in C.J. Beyers, (red.), SuidAfrikaanse biografiese woordeboek III (Kaapstad, 1977), p. 836.

P.R. Kirby, A source book on the wreck of the Grosvenor, p. 36.

P.R. Kirby, A source book on the wreck of the Grosvenor, pp. 72, 126. One of the survivors, John Hynes (Heins), gave the "Malay's" name as Trout. D.C.F. Moodie, The history of the battles and adventures of the British, the Boers, and the Zulus \&c., in South Africa I (Cape Town, 1888), p. 126. 
These accounts leave more questions than answers. Is this a reference to an absconding slave, a "Malay", a Muslim afraid to return to the Christian region, or perhaps the survivor of an earlier shipwreck? ${ }^{16}$

In Van Reenen's report on his expedition to the wreck of the Grosvenor, the uncertainties become even more pronounced. They met a "so called Englishman", who spoke Dutch to them and who, according to the inhabitants, was a survivor from the ship. He himself purported to be a free man who had sailed in an English ship from Malacca [Melaka] and promised to take them to the wreck. When he failed to honour his promise, Van Reenen concluded that he was an absconding slave. Their suspicions were confirmed by Moses, a member of the party, to whom the Englishman was to have said that he had a wife and two children in the Cape and that he had even known Van Reenen's father. Van Reenen also wrote that they had visited a hamlet of "bastard Christians" "... where we found that the people were descended from whites, some too, from slaves of mixed colour, and natives of the East Indies." 17

From the above, only one valuable inference can be made, that is that before the end of the 18th century, escaped slaves, among whom some might have had a Muslim background, were found in the district of Graaff-Reinet and further eastward. Their influence was not clear and, according to no verified evidence, of permanent importance in the establishment of a Muslim culture along the eastern border of that time.

\section{The Javanese Artillery and the Battle of Blaauwberg}

Two wars are connected to the history of Muslims in the Eastern Cape - the Battle of Blaauwberg (1806) and the War of the Axe (1846) when Muslims, together with others, were sent to this part of the country to assist in defending the eastern border.

In November 1804, a Javanese corps was founded by General J.W. Janssens. ${ }^{18}$ It comprised free men who had to take an oath of allegiance to the Batavian Republic. ${ }^{19}$ Frans van Bengaalen was appointed "veldpriester" (field priest) on 1 November. ${ }^{20}$

16 G. Thompson, Travels and adventures in Southern Africa II (Cape Town, 1968 [1827]), pp. 236-237.

17 D.C.F. Moodie, The history of the battles and adventures of the British, the Boers, and the Zulus \&c., in South Africa I, p. 73.

18 G.M. Theal, History of South Africa from 1795 to 1872 V(1) (Cape Town, 1964 [1915]), pp. 189-190. A second corps, the Ligte Javaansche Artillerie te voet was also formed and under the command of the Frenchman, J. Madlener. Frans van Bengaalen could, apart from his religious position, also have been in charge of the Javaansche Artillerie? Lyst van alle collegian, civile en kerkelyke ambtenaaren, in de Bataaffsche Volkplanting Zuidpunt van Africa (Kaapstad, 1805), s.p.

19 D.W. Krynauw, Beslissing by Blouberg (Kaapstad, 1999), p. 24. The oath, published in the Caapse Courant 1804-11-03, reads: Ik beloove en zweere by den Eenigen en Almachtige God en Zyner grooten Profeet Mohamet trouw aan de Batafsche Republiek, dit land onzer inwoning, tegen alle vyanden van den Bataafsche Republiek te beschermen.

20 Lyst van alle collegian, civile en kerkelyke ambtenaaren, in de Bataaffsche Volkplanting Zuidpunt van Africa (Kaapstad, 1805), s.p. Van Bengaalen played an important role in the early history of the Cape. In 1800 , he addressed a petition on behalf of the Cape Muslims to Governor George Yonge in which application was made for a site to erect a mosque. Cape Archives Depository, Cape Town (henceforth CAD): S.O. 1799-1800, Letters despatched within the Colony, item 236, p. 44. On 2 October 1805, a piece of land, the Tana Baru 
In the traditions of the Muslims of Uitenhage, it is told that the first Muslims were descendants of slaves who had left the Cape for the eastern border since 1806. Abrahams declares emphatically:

What is known is that in 1806, rather than be conscripted into the army, eighty nine Muslims ran away or absconded from Cape Town and made their way to Uitenhage. The names of these Muslims are apparently recorded in the Cape Archives but have not yet been traced. ${ }^{21}$

Although this might be true, no documentary proof of this could be found. Rochlin says that the first Muslims who actually found their home in Uitenhage were slaves who had escaped from the Cape in 1809 and had settled permanently in the town. ${ }^{22} \mathrm{He}$ used Sellick as source:

But about 1809 a number of slaves escaped from Capetown (sic) and made their way to Uitenhage. As an inducement to them to go back again, the Government generously guaranteed them a free par-don-provided they returned to service within four months from the date of the notice. Whether they took advantage of this noble offer deponent sayeth not, but it is scarcely likely that they fell in with the idea. ${ }^{23}$

Abrahams repeats Rochlin's statement and adds:

But it is scarcely likely they fell in with the idea. This then must surely be sufficient proof that the slaves who ran away had already been conscripted because if they had not been conscripted, why would the Governor offer them a free pardon. ${ }^{24}$

These statements need revision. First, there was no evidence that the escaped slaves were Muslims and Sellick acknowledged no source for his statement which was simply repeated by Rochlin. Secondly, no reference is made to the slaves that they were commandeered, as Abrahams assumed. The proclamation of Governor Caledon does not refer to conscripts, but only to "Runaway Slaves, who might be induced to return to their duty upon a promise of pardon being held out to them ..." and furthermore that they had absconded from their "Masters and Mistresses." 25 The exemption appears to be only from punishment because they had absconded.

\footnotetext{
("new ground"), was allocated to Van Bengaalen to be used as cemetery for the "Javanese". It was next to the section they had, until that date, used unofficially for the same purpose. CAD: RDG2, Notules van die Raad der Gemeente, 1805-10-02, pp. 149-150. A.G. Abrahams (ed.), Muslim heritage and ancestry Port Elizabeth and Uitenhage (Port Elizabeth, 1988), s.p.

S.A. Rochlin, Origins of Islam in the Eastern Cape, Africana Notes and News 12(1), 1956, p. 22. W.S.J. Sellick, Uitenhage past and present. Souvenir of the centenary 1804-1904 (Uitenhage, 1904), p. 6. A.G. Abrahams, (ed.) Muslim heritage and ancestry Port Elizabeth and Uitenhage, s.p. Robert Shell also relies on Rochlin. R. Shell, The march of the Mardijkers: the toleration of Islam at the Cape, 1633-1861, Kronos 22, November 1995, p. 18. See also: R. Shell, The making of the population of Port Elizabeth, Looking Back 40, November 2001, p. 43. Cape Town Gazette, and African Advertiser 180, 1809-06-24.
} 


\section{The Cape Town Malay Volunteers and the War of the Axe}

The names of Muslim individuals appeared in documented history in the 40 years between the two wars mentioned. The War of the Axe (1846) has a special place in the development of their history in the Eastern Cape. There was the expectation that Muslims would eventually get a site in Cape Town where they could erect a mosque and that their participation would ensure this grant. Cape and Eastern Cape Muslims met each other. According to the literature, some of the volunteers stayed on in the Eastern Cape after the war and were involved with the construction of the mosque in Uitenhage.

On 22 April 1846, Governor Sir Peregrine Maitland (1777-1854) had martial law promulgated in the Colony. ${ }^{26}$ Messages were sent to all the Civil Commissioners to gather the available men between the ages of 16 and 60 and to send them to the eastern border without delay. ${ }^{27}$

On May $4^{\text {th }}$, crowds met in Church Square anxious to be enrolled for service. Conspicuous was a number of Malays eager to serve. A Company of them was eventually formed and sent round to Algoa Bay by sea. ${ }^{28}$

The Cape Town Malay Volunteers (CTMV), ${ }^{29}$ mostly abbreviated to the Malay Corps, eventually comprised 214 men of whom 151 had joined voluntarily, 31 had been drafted and 9 were recruits. The leader corps comprised 22 officers, non-commissioned officers and imams. ${ }^{30}$ On 14 May, two divisions boarded the Mountain Maid and departed to Algoa Bay $^{31}$ where they arrived on the 22nd, while the third division arrived in Post Elizabeth four days later on board the Phoenix..$^{32}$ On 28 June, they marched into Graham's Town behind their green banner and the "soldierlike appearance" made a good impression on the reporter of the Herald. ${ }^{33}$

CAD: C.O. 5836. Government Proclamations, Notices, Ordinances, Circulars and Statistical Register, 18061909. Proclamation by Maitland, 1846-04-22.

CAD: C.O. 5921. Cape of Good Hope Ordinance and Acts, 1844-1854, 1846-04-30; G.E. Cory, The rise of South Africa V (Cape Town, 1965 [1926]), p. 436.

CAD: C.O. 5921. Cape of Good Hope Ordinance and Acts, 1844-1854, 1846-04-30; G.E. Cory, The rise of South Africa V, p. 436.

G. Tylden, The Armed forces of South Africa (Johannesburg, 1982), p. 111.

National Library, Grey Collection, 16c. List of Cape Town Burgher Force, Volunteers, Malay and Liberated African Corps, Burgher Force of Cape District, pp. 14-18, 46.

B. Aldridge, Cape Malays in action, Quarterly Bulletin of the South African Public Library 27(2), December 1972, p. 25.

Eastern Province Herald, 1846-05-23; 1846-05-30.

Eastern Province Herald, 1846-06-20. The flag comprised a green background with a Union Jack in one corner, three crescents and the words Allah-u-Akbar (God is Great) in the middle. For a reconstruction of this, see: W. Steenkamp, Poor man's bioscope (Cape Town, 1979), p. 17. 
As in 1806, when Frans van Bengaalen was the field priest of the Javanese Artillery, imams were indispensable as part of the war effort. Prayers were conducted regularly. The best-known figure involved was imam Achmat Sadic Achmat, the youngest son of Achmat van Bengaalen and Saartje van de Kaap, on whose property the first mosque in the Cape had been established in c $1798 .{ }^{34}$ During the war, he played the double role of lieutenant and imam and he was presented in this capacity by Thomas Baines. ${ }^{35}$ He returned to the Cape and from 1872 to 1878 , he was the imam of the Auwal mosque.

The CTMV was not properly trained for the task that lay ahead. ${ }^{36}$ The soldiers' training was skimpy and at least one observer, the Physician General, William Munro, was not convinced that they knew how to use their weapons. ${ }^{37}$ Furthermore, they were involved in a mutiny and refused to march to the estuary of the Fish River when it was discovered that the government had not provided the promised rations to their families in Cape Town. ${ }^{38}$ Harret Ward left an interesting description of their attitude after the incident:

They take the war coolly enough, and when off duty, lie about the green in the warm and moonlight nights, whistling and singing the most harmonious chorusses (sic). They will not enter the bush, and have never been of use in rescuing cattle. ${ }^{39}$

However, when they were discharged on 16 September 1846, they were thanked for their help in vanquishing the enemy:

His Excellency desires them to accept his thanks for the services which they have rendered in arms ... Many of them, besides encountering the peril of war, have been exposed to great fatigue and privations, un-avoidable under the peculiar features of the warfare in which they have been engaged. It will be their satisfaction here-after to remember that what they endured was on behalf of their country, to which in the time of need they have faith-fully performed the duties of citizens. ${ }^{40}$

Achmat Davids has questioned their eagerness to serve, as well as the loyalty of the Muslims to the Colonial government and their war effort. He is of the opinion that their involvement could rather be attributed to the fact that the Muslims regarded involvement as a barter transaction in terms of which they would eventually acquire a mosque site. In this, he is supported by Abdul Kader Tayob. ${ }^{41}$ The mutiny may thus be seen against this background as

CAD: MOOC 7/1/188, no. 131. Will of Saartje van de Kaap, 1841-12-01.

M. Diemont \& T. Diemont, The Brenthurst Baines (Johannesburg, 1975), pp. 40-41.

Eastern Province Herald, 1846-06-20.

W. Munro, Records of service and campaigning in many lands (London, 1887), pp. 117-119.

G.E. Cory, The rise of South Africa V, p. 466; Eastern Province Herald, 1846-05-16.

H. Ward, Five years in Kaffirland II (London, 1848), pp. 20-21.

M. Kollish, The Mussulman population at the Cape of Good Hope (Constantinople, 1867), pp. 21-22.

The grant of a site to erect a mosque in Cape Town was indeed made in 1851. A. Davids, The mosques of Bo-

Kaap, pp. 139-140; A.K. Tayob, Islam in South Africa: Mosques, imams and sermons (Gainesville, 1999), pp. 37-38. 
the British allegedly did not fulfil their promises and through this behaviour also involved the promised mosque site.

After the war, many of the Muslims stayed on in the Eastern Cape ${ }^{42}$ and Davids is of the opinion that they might have been involved in the establishment of the mosque in Uitenhage. ${ }^{43}$ Abrahams also states that the Volunteers did not return to the Cape, but any involvement they might have had with the establishment of the mosque was not recorded in the Eastern Cape. ${ }^{44}$

By 1846 there already was a large number of Muslims in Uitenhage, Graaff-Reinet, Port Elizabeth and Graham's Town. From 1816, their names appeared in documented information such as the records of the Slave Office in Uitenhage. It was during this same time that the first individuals came to the fore and became involved in matters of the faith. One of the manifestations of this development was the establishment of a place of worship in what was the most important town in the region at that time.

\section{Uitenhage}

In 1804, the district of Uitenhage was cut largely from the existing Graaff-Reinet, but also from a section of Swellendam and created under the magistracy of Captain J.C.L. Alberti (1768-1812).

Alberti himself selected the site for the town where the drostdy would be erected. It was the loan-farm Rietvallei of Betje [Elizabeth], the widow of Gerhardus Scheepers, along the Zwartkops River. ${ }^{45}$ For his choice, he argued that the area was healthy, that there was abundant and good water, the soil was fertile, timber and fuel wood were readily available and bricks could be fired, that there was sufficient space to set out a large number of stands and that it was situated only six hours on foot from Fort Frederick - where he had been appointed commander the previous year and where he also stayed on for the time being. ${ }^{46}$

The choice of the site was regarded as a happy one by contemporary travellers and officials. Although the 1820 settler and later founder of Aliwal North, John Centlivres Chase (1795-1877), in 1843 disapproved of the borders of the region, among other things because by that time, Graham's Town presented a much more convenient alternative for many of the state's affairs that had to be concluded in Uitenhage, he praised the location, abundance of water and lush gardens. ${ }^{47}$

\footnotetext{
42 A.K. Tayob, Islam in South Africa: Mosques, imams and sermons, p. 38. The list of Muslim Volunteers is currently being checked to test the information.

43 A. Davids, The Mosques of Bo-Kaap, p. 141.

44 A.G. Abrahams (ed.), Muslim heritage and ancestry Port Elizabeth and Uitenhage, s.p.

45 The farm of "Kat Skyppers", where one of the survivors of the Grosvenor, Thomas Lewis, in 1783 stayed on for two months to recover from his ordeal. P.R. Kirby, A source book on the wreck of the Grosvenor, p. 45. G.E. Cory, The rise of South Africa I (Cape Town, 1965), p. 140; C. Potgieter, Uitenhage, in D.J. Potgieter, et al. (eds.), Standard Encyclopaedia of Southern Africa XI (Cape Town, 1975), pp. 40-41; J.P. van der Merwe, Die Kaap onder die Bataafse Republiek, 1803-1806 (Amsterdam, 1926), p. 131. J.C. Chase, The Cape of Good Hope and the Eastern Province of Algoa Bay (Cape Town, 1967 [1843]), pp. 54-55.
} 
In 1823, the traveller, prospector and businessman, George Thompson (1796-1889) predicted that it would become the most densely populated and most important town of the eastern part of the Colony, since Port Elizabeth, except for its location on the seaboard, could not compete in any way with the advantages Uitenhage had to offer. And Thomas Baines (1820-1875), even though he did not visit the town in 1848, nevertheless spelled out its excellence:

[Uitenhage] ...was described to me as one of the most beautiful country towns in South Africa. It is situated on the left bank of the Zwartkops River, about fifteen miles from its mouth and eighteen or twenty from Port Elizabeth; its spacious streets intersect each other at right angles, and its gardens, from which most of the fruit used in the last-mentioned town is supplied, are watered by a never failing stream from the Winterhoek Mountains about six miles distant. The mineral treasures of the district, from which Port Elizabeth has since been separated, are supposed to be rich and abundant; veins of lead and copper have long been known to exist ... ${ }^{48}$

To N.J. Merriman, the "wandering bishop", in 1849 the town looked like an oasis; it has to be added, after an exhausting and eventful journey from Graham's Town on 5 March:

After this I proceeded direct to Uitenhage, but through such heat as I had not before experienced in Africa. When I got over the crown of the small hill at the foot of which Uitenhage lies and heard the gurgling of water and witnessed the luxuriant vegetation of that place, while all the country round was burnt up, I was ready to cry for joy. The physical comforts of Uitenhage refreshed me much. Splendid peaches in abundance were served at breakfast, dinner and tea. Pears and water melons too we had ad libitum... ${ }^{49}$

These high expectations were put to shame and in 1823 Thompson already indicated that the town was not growing according to the earlier promise:

Nevertheless, Uitenhage, with all its natural advantages, and its convenient position for becoming the emporium of the eastern districts, has not increased of late in any degree commensurate with its apparent capabilities, or in comparison with some other places on the frontier. ${ }^{50}$

The growth of Port Elizabeth and Graham's Town after the arrival of the British settlers by the 1820 s hampered the growth of Uitenhage to a noble city as foreseen by Chase. He

\footnotetext{
48 T. Baines, Journal of residence in Africa 1842-1853 I (Cape Town, 1961), p. 24.

49 D.H. Varley \& H.M. Matthew (eds.), The Cape Journals of archdeacon Merriman 1848-1855, p. 27.

50 G. Thompson, Travels and adventures in Southern Africa I (Cape Town, 1967 [1827]), p. 13.
} 
indicated that there were 350 houses and 1500 residents in the town, but that "its growth has been greatly retarded by its more successful rival Graham's Town, the capital of the province, on one side, and the neighbouring town of Port Elizabeth ..."

In the years Thompson described, the influence of the new towns was not yet so strong and he promoted Uitenhage enthusiastically as an ideal point of departure for the new immigrant in the Colony:

His preliminary preparations being made, the emigrant should, if possible, secure a passage direct to Algoa Bay, in preference to Cape Town, - unless he means to establish himself within a moderate distance of the latter, which would require, however, a more considerable capital than I have taken into account. Cape Town is comparatively an expensive place... while, on the other hand, by proceeding at once to Uitenhage, he could maintain his family in that village, or its vicinity, at a very moderate rate, until he had leisure to look about for such an estate as suited his circumstances. At Uitenhage, house-rent is moderate, - vegetables are abundant, - good beef is sold for $1 \mathrm{~d}$. per lb., and mutton for $11 / 2 d$. Several genteel eastern districts, the population must rapidly increase. ${ }^{52}$

It was in this period that the first Muslims in Uitenhage and the Eastern Cape emerged in both oral and written history and also embraced the opportunities spelled out by Thompson.

\section{The first Muslims}

It may be assumed that the first Muslims to become involved with their faith in an organised way in the Eastern Cape, as in Cape Town, Stellenbosch and the Strand, have to be sought in the free black and slave groups.

Between 1808 and 1830 the slave numbers in Uitenhage remained mostly constant with an average of 760 in the first, 880 in the second and 1032 in the third decade of the century. ${ }^{53}$ Who or how many of these slaves were Muslims is difficult to say. Here, we can rely only on names and origins ("surnames"), although these are not infallible sources. Samuel Eusebius Hudson (1764-1828), who built a house in Uitenhage in the early 1820s, wrote in

51 At that time, there were 8368 inhabitants. It is not clear whether the 14 ministers he listed separately were included in the total. J.C. Chase, The Cape of Good Hope and the Eastern Province of Algoa Bay, pp. 56-57, 141.

$52 \quad$ G. Thompson, Travels and adventures in Southern Africa II, p. 125.

53 These figures have been compiled and calculated from various sources. CAD: GH 28/2. Enclosure to dispatches; SO 7/31. Return of slaves at the Slave Registry office Uitenhage 1816-1829; S.O. 7/34. Return of the number of slaves registered at the Cape of Good Hope on the $31^{\text {st }}$ of December 1830, p. 4; G.M. Theal, Records of the Cape Colony VII-XXXV (Cape Town); W. Bird, State of the Cape of Good Hope in 1822 (Cape Town, 1966 [1823]), p. 107; M.D. Teenstra, De vruchten mijner werkzaamheid (Kaapstad, 1943 [1830]), p. 258. 
his diary that most of the slaves were Malays and Buginese. ${ }^{54}$ However, a partial study of the records of the Slave Office indicates that most Uitenhage slaves had been born in the Cape (which nevertheless could mean that they were of Oriental origin), the second mostly from Mozambique and the rest scattered from Madagascar to Ternate, with the Mozambicans three times more than the rest put together.

The names of three free blacks appear in the Register of the Slave Office in Uitenhage, Jan Berdien, Trona (1820) and Tjiewie (1825). Abdol, Slamat, Corridon and "surnames" such as Bengale, Bougies, Batavia, Tranquebar, Madras and Malabar are common among the names of the slaves themselves. In return records, free blacks in Uitenhage are indicated only in 1824, although space had been left for this on the lists since 1818. In that year, one adult male, one boy under the age of 16 and two girls were counted. These figures do not tally with those of the register of slaves and it is unclear to whom reference was made. This explication does not agree with that of Berdien's family and for some reason, it should refer to another free black. ${ }^{55}$

Until 1843 there was no further official reference to Muslims in the Eastern Cape, but in that year, Chase recorded 50 in Albany, 50 in Graaff-Reinet and 150 in Uitenhage. ${ }^{56}$

It was around this group that the first mosque was established, but there is no oral or documented history of where they had worshipped before that time. The early Cape custom of worship in homes could also have applied in this case.

In existing records, the names of two Muslims appear almost simultaneously. According to Thomas Pringle (1789-1834), who arrived in Algoa Bay on 15 May 1820, Fortuin Weis [sometimes Weys, Weiss] had already settled in Port Elizabeth and was one of the first to have built a house there:

The only other house then commenced, excepting the temporary offices and cabins already mentioned, was one erecting by a Malay named Fortuin, now, I understand, one of the wealthiest and most respectable inhabitants of the place..$^{57}$

In the same year, on 20 October, the name of Jan Berdien was recorded in the Slave Office as owner of two slaves. ${ }^{58}$ Both Weis and Berdien would eventually play important roles in the rise of Islam as an organised religion in the Eastern Cape.

CAD: Accession 602, vol. 8, s.p., Diary of Samuel Eusebius Hudson. CAD: MOOC 6/9/123, no. 4440, Death notice of Jan Berdien, 1868-06-03.

J.C. Chase, The Cape of Good Hope and the Eastern Province of Algoa Bay, p. 141.

T. Pringle, Narrative of a residence in South Africa (Cape Town, 1966 [1834]), p. 21. On the arrival of the 1820 settlers, "Malays" were noticed and there is a description of Elijah Pike, then a young boy, who was carried to the beach by one of them upon their arrival. E.K. Lorimer, Panorama of Port Elizabeth (Cape Town, 1971), p. 33; Another settler, J.S. Reed, remembered that when they landed on 5 April 1820, only five houses could be seen. One of those was that of "old Fortuin Ways (sic) a wealthy Malay." W.J. Reed \& J.S. Reed, Settler memories, Looking Back 20, 1980, p. 22.

CAD: S.O. 6/144, folio 41; S.O. 7/31, Return of slaves registered at the Slaves Registry Office, Uitenhage 1816-1829. 
According to tradition, Weis, who was indicated in 1822 on a list of the residents of Port Elizabeth, owned six or seven properties in the central part of the town, more than one house and stand in Port Elizabeth, as well as wagons and oxen, which he left to his heirs when he died on 6 April 1838. He was the founder of Islam in Port Elizabeth. ${ }^{59}$ The first mosque in Grace Street (c 1855) was built on a site that first belonged to him and later to his wife, Doortje [Dietjie] of the Cape. ${ }^{60}$ Abrahams speculates that he, Weis, went to the Eastern Cape in or after 1806, but, according to his will, he might still have been in the Cape in $1813 .{ }^{61}$ At that time, he had a previous will drawn up by Notary Jacobus Petrus de Wet. ${ }^{62}$

In his turn, Jan Berdien [sometimes Bardien] was directly involved with the establishment of a mosque in Uitenhage, approximately a decade before the first mosque was built in Port Elizabeth.

Abrahams provides the following information about Jan Berdien, based on oral history and documents in possession of the community:

The pioneer of the Muslims in Uitenhage is a man named EMAAM JABAAR-U-DIN, also known as Abdul Maalick. As Jan Bardien and also Jan Berdien, Emaam Jabaaru-din was the son of a woman known only as EVA and of Prince Shams-u-din also known as Asamadin who was the son of Sultan Nabier, Ruler of Macassar, Java and Riyah Sitta Riyah, born in Kuala Lampur, Indonesia.

Born at Cape Town in 1784 he came to Uitenhage in 1815 at the age of 31.

Emaam Jabaar-U-Din was responsible for building the Mosque in Uitenhage.

Emaam Jabaar-U-Din ... was married to a woman named Galia. From the marriage four children were born (viz.) Gatiesa, Abdul Kariem, who later became Emaam, Abdul Kahaar also an Emaam and Nafiesa.

Emaam Jabaar-U-Din died in Uitenhage on 3 June 1868 at the age of 84 years. He was buried in Uitenhage cemetery. The death notice filed on 23 June 1868 No. 4440 records his name as Jan Berdien Mohammedan Priest and records the name of his parents as Asamadin and Asa (Malays).

Because so much of the history with which we work is locked in the community's memory, it would be meaningful to check this information for correctness.

\footnotetext{
59 D.J. Potgieter, Standard encyclopaedia of Southern Africa (Cape Town, 1973), vol. 9, p.14. On this list, he is recorded as a blacksmith. A. Porter, Griffin Hawkins's list of inhabitants of Port Elizabeth in 1822, Looking Back 18, 1978, p. 22; CAD: MOOC 6/9/12, no. 2689, Death notice of Fortuin Weis, 1838-04-06. Weis could most probably also be regarded as one of the founders of Port Elizabeth. A.G. Abrahams (ed.), Muslim heritage and ancestry Port Elizabeth and Uitenhage, s.p. His daughter, Asia, was born c 1802 in Cape Town. CAD: MOOC 6/9/139, no. 8168, Death notice of Asia Weys, 1872-04-16.

62 CAD: MOOC 7/1/145, Combined will of Fortuyn Weys [sic] and Dortje [sic] van de Kaap, 1833-03-24; MOOC 6/9/143, no. 9128, Death notice of J.P. de Wet, 1847-08-31.
} 
Abrahams's information from the death certificate and a translated copy of his will, still in possession of Imam A. Sirkhotte of Uitenhage, is correct, except for the fact that there is an extra $e$ in his name (Asamadien vs Asamadin). Furthermore, his mother's name is recorded as Eva, and not Asa. Because he was born in the Cape, it means that his parents, or at least his mother, had to have been here. The tradition that his father was a prince and the son of the Sultan of Macassar has not been established in documents, but what is significant, is that he was already known under a Muslim name, Asamadien. Jan Berdien signed his name in Arabic as Imam Jabar El-din (literally splint or support of the faith). ${ }^{63}$ His grave and headstone are in the cemetery. The names of his wife and children are correct, but for the omission of his first born son, Marach, a sickly child who died at the age of twenty and was never occupied in any trade. Another discrepancy is that the name of Abdol Kariem (Bardien) is listed before that of his older brother, Abdol Kahaar. From their death certificates it is clear that Abdol Kariem was born about two years after Abdol Kahaar. Abdol Kariem was literate and followed in the footsteps of his father to become the imam of the Caledon Street mosque; Abdol Kahar signed his name by means of a cross. Although Abrahams says that also he was an imam, there is no mention of this on his death certificate where his trade is indicated as cutter and tailor. $^{64}$

Marach was born in Cape Town on the $28^{\text {th }}$ of December 1814. Abdol Kahaar was born in Uitenhage and died in 1884 at the age of 70 years, according to his death notice. This means that he was also born in 1814, but the ages recorded on death notices are not always correct and it is clearly impossible. But it does mean that the family arrived in Uitenhage during 1815. By 1820, Jabar El-din was already established so well that he could buy two slaves.

He was an affluent person and left more than one built-up property in Port Elizabeth, and one in Hout Street in Cape Town to his children (provided that they saw to it that an amount of money be paid out to his second wife, Rabea) and various amounts of money to his grandchildren. His four children acquired more property in Caledon Street, Uitenhage, and the daughter of Saval Omar ${ }^{65}$ and the daughter of Abdol Kariem a property with house in Durban Street, Uitenhage, and finally the mosque was bequeathed to the Muslim community: The E, which does not exist in Arabic can be read alternatively as an A or a U. Death notice of Abdol Kahaar Berdien (sic), 1884-06-20; MOOC 6/9/417, no. 4576, Death certificate of Abdol Kariem Bardien (sic), 1900-12-05. Abdol Kahaar named his first born after his dead brother. died when the mosque was founded in 1880 . He might be confused with imam Fiedienie Savahl who was involved with the founding of that mosque. He probably led prayers in a house mosque. He died in 1876 on a pilgrimage in Jeddah. CAD: MOOC 6/9/155, no. 2740, Death notice of Sawal (sic) Omar, 1876-05-02; MOOC 6/9/8, no. 1535, Death notice of Sophia (Omar), 1836-05-17; S.O. 7/31, Return of slaves registered at the Slaves Registry Office, Uitenhage 1816-1829, folio 4, Petrus Johannes Heugh. My thanks to Jackie Loos for this clue. 
Ten zevenden is het de wil en begeerte van den testateur dat zekere stuk grond in Uitenhage waarop een moskee staat, niet zal worden verkocht, maar dat dezelve met de daarop staande moskee gratis sal worden afgestaan als een bedehuis der aldaar resideerende Mahomedanen tot des testateur's secte behorende, zoolang te Uitenhage stad eenige zoodanige Mahomedaansche gemeente bestaat, met vrylating aan de gemeente om daarop een school, ter hunnen kosten, voor hunnen kinderen, te bouwen ...66

This erf 2899 (now a part of erf 24686) on the corner of Caledon and Cuyler Streets in Uitenhage was acquired on 4 November 1845 by Jan Berdien from Michael Arnoldus Muller. ${ }^{67}$ Abrahams states that the government donated the erf to the Muslims in 1840 in recognition of their participation in the War of the Axe. It is obvious that the date is wrong and Muslims were involved in the war only in 1846. In the deed there is no indication that the erf was allocated to the Muslims, although the erf surveyed in 1835 was indeed allocated to the widow of Hendrik Langenbach. Hence, we should assume that Jan Berdien himself bought the erf.

The only further references to him in official records were on 14 February 1827 and 24 August 1831 when he bought another two slaves. One was a seamstress, the other a housemaid. ${ }^{68}$ After his death, first his son, Abdul Kariem Berdien, succeeded him as imam of the mosque, and later his grandson, Ebrahiem Bardien. Another grandson, Abdurakiep (Kippie) Berdien, son of Abdol Kahaar, later became an imam in Wynberg. ${ }^{69}$ A handwritten Qur' an that used to belong to Jabar El-din is still in the family's possession.

Other prominent names in the community's memory are those of the Salie, Rafie, Largadien, Agherdien and Jappie families. In some way, all of them were directly involved with the founding and growth of the oldest mosque communities in Port Elizabeth and Uitenhage. The history of these families requires further study.

\section{The first mosque in South Africa}

One of the aspects of the history of South African Muslims that kept various researchers occupied was the founding and construction dates of the oldest mosques. Early descriptions

\footnotetext{
66 In the seventh place, it is the will and wish of the testator that a certain piece of land in Uitenhage on which there stands a mosque shall not be sold but that the same shall be ceded free of charge as a house of prayer to the Mohamedans residing there and belonging to the testator's sect for as long as any such Mohamedan community exists in Uitenhage, with the freedom for the community to build a school, at their cost, for their children. CAD: MOOC 7/1/297, no. 94A, Will of Jabarodien (Jan Berdien), 1868-03-31. Deeds Office, Erf 2899, Uitenhage, 1845-11-04.

CAD: S.O. 6/144. Folio 41, Return of slaves registered at the Slaves Registry Office, Uitenhage 1816-1829. CAD: MOOC 6/9/777, no. 414. Death notice of Abdol Kahaar Berdien, 1884-06-20; CAD: MOOC 6/9/802, no. 2798, Death certificate Emam Abdurakiep Berdien, 1915-06-16.
} 
of travellers and officials often confused the picture through inaccuracy and misunderstanding. John Mayson, who studied the Muslim presence in Cape Town in 1854 and had discussions with several other Muslims, wrote as follows:

There is only one mosque in Cape Town. This large, substantial, but plain and unminaretted edifice has lately been erected with the concurrence and favoured by the patronage of the municipal authorities: with an implied guarantee that it was to be used by the Mahometans in common, irrespective of their misunderstandings. It is occupied by one section of them only.

The Jamia mosque in Chiappini Street to which he referred, was actually the fifth mosque in Cape Town and hence his observation was incorrect, but he was not the only visitor to make this mistake. Furthermore, Mayson was under the impression that the new mosque had replaced an older one and that the other places of prayer were not mosques but langars (house mosques or prayer chapels). He continued:

A smaller mosque was used before the present one was built; before its erection the Malays performed their religious services in the adjacent stone-quarries. There are about twelve chapels or mosjids, for daily service, in the houses of the superior priests. ${ }^{70}$

What did make the Jamia mosque exceptional - and why Mayson regarded it as the only one, was the fact that it was the first Muslim building for prayer that had been separated from the surrounding urban mesh and stood as an independent and clearly recognisable mosque. ${ }^{71}$ It was also much larger than the others that had grown in and out of houses and retained their homely appearance.

The history of the first mosque in the Cape has already been researched in detail and today there is little doubt that it is the Auwal mosque in Dorp Street. As Muslim school, or madrasa, it dates from c 1794 and as mosque from c $1798 .^{72}$

It was followed by the Palm Tree mosque in Long Street (established between 1807 and 1820), the Noorel Islam mosque in Buitengracht Street (c 1844) and the High Way mosque in Claremont (c 1851). ${ }^{73}$ From the work of Mayson, it could be deduced that the

J.S. Mayson, The Malays of Cape Town (Pretoria, 1970 [1861]), p. 21. On p. 32 he wrote that "Malays are now in many parts of the Cape colony. At the village of Claremont, only four miles from its chief city, they have lately built a mosque." Evidently he did not regard it as one of the mosques of Cape Town itself.

71 S.W. Le Roux, Vormgewende invloede op die ontwikkeling van moskee-argitektuur binne die Heilige Sirkel (D.Phil-proefskrif, Universiteit van Pretoria, 1992), pp. 199-201. dates, they are close enough to the actual years in which the mosque was established. The dates are being studied with the aid of further information. 
Jamia mosque was completed by the beginning of April $1853 .{ }^{74}$ In 1857 , transfer of the property was effected from the Municipality of Cape Town to Abdol Wahab, surviving trustee for the Mahometan community. ${ }^{75}$

The mosque was built on the site that had been granted to the Muslim community after the War of the Axe and was known as the Queen Victoria mosque on account of this. It was the first mosque in Cape Town that was built on a site set aside specifically for this purpose and the first that was conceptualised typologically as a place of prayer. ${ }^{76}$ According to Achmat Davids, the communal use by all Muslims was an explicit prerequisite for the grant.

\section{Masjid al-Qudama, Caledon Street, Uitenhage}

From Merriman's description, it is deduced that the mosque in Caledon Street was a completed building by March 1849. Jabar El-din acquired the stand in November 1845 which contradicts the date on the current plaque at the new entrance. It is impossible for the mosque to have been completed that same year. No further information could be traced according to which the date could be determined more accurately. However, it should be in the years from 1846 to 1848 . Consequently, the Caledon Street mosque is the fourth oldest mosque in South Africa, the first to be built on a site dedicated to worship and the first to be conceptualised as a place of prayer, complete with minaret, and not having grown gradually inside or from an existing building like the first three in Cape Town. The process was completed at least three years before the first free-standing mosque was erected in Cape Town.

At present, the original building has been completely swallowed up by alterations. Minor alterations and modifications date from before 1957, but in 1966 the original form was still recognisable. ${ }^{77}$ In 1974, the mosque was rebuilt and in 1999, all links with the original disappeared as a result of another rebuilding. Even the historical minaret, that had most probably been the first in South Africa, was replaced in this process with twin towers. ${ }^{78}$ The problem stated at the beginning of this article is whether the original appearance could be reconstructed at least on paper.

The only and provocative description of it is by Merriman:

The Dutch church at Uitenhage is rather an imposing edifice and while the bell sounded out from its tower calling the inhabitants to worship, and the like sound proceeded both

\footnotetext{
74 J.S. Mayson, The Malays of Cape Town, p. 28. He wrote that it was inaugurated before the death of imam Abdol Bazier. Bazier died on 27 April 1853. CAD: MOOC 7/1/215, no. 54. Will of Abdol Bazier, 1853-05-09. Deeds Office, Erf 934 Cape Town, 1857-12-14.

A. Davids, The Mosques of Bo-Kaap, p. 138. This is if one should follow Mayson's lead and disregard the Claremont mosque.

A.P., Outing to Uitenhage, Looking Back 6(3), 1966, p. 13.

City Council of Uitenhage: Plans: No. 129, approved 1957-09-12; No. 694/73, approved, 1973-12-12; No. 332/86, approved 1987-01-19. I am grateful to Yusuf Agherdien for providing a full set of the 1987 plans.
} 
from the Wesleyan Chapel and the Independent chapel for the natives, and even the mosque (the only regular one, I believe, in the Colony) reared its dome and gilded minarets, with the crescent proudly figuring at the top of each, we, the Church of England worshippers, crept in silence to what appeared to me a peculiarly profane building - the Court House... ${ }^{79}$

According to him, there was a dome and two or more minarets. This laconic remark does not at first glance appear to be in line with the evidence provided by the structure and two undated photographs published by Abrahams.

In 1957, ablution facilities and a canteen were added on the southern side and connected directly to the large room that had already been added to the mosque before this date. The existing free-standing ablution facilities on the northwestern boundary were removed and replaced by two toilets. The older room served as madrasa and for travellers to stay overnight and was accessed from Cuyler Street. It was added to the mosque after 1868, but before 1939 when it is clearly discernable on an aerial photograph. ${ }^{80}$ The madrasa was later connected to the mosque space by means of concertina folding doors. By opening the doors, it could serve as extension to the prayer space on big occasions. Events such as the Prophet's birthday or Mawlud were also celebrated here. ${ }^{81}$

The plan of 1973, as submitted to the Municipality, is of value because the older plan is still discernable. The original plan has been unravelled from this. Although the plan of the older building was not drawn quite correctly, it could be brought to scale with the help of the photographs.

The mosque was erected parallel with the street grid, with the result that the prayer orientation had to be adjusted by means of the carpet layout and the worshippers had to conduct their prayers diagonally to the space. ${ }^{82}$ Because of the Group Areas Act, that did not allow any new construction work outside the existing area of the mosque or the erection of a completely new building, this arrangement was retained, even with the alterations in 1974. As a result of the weakened building materials, which resulted in large parts of the walls collapsing during the rebuilding, the mosque had, ironically enough, to be rebuilt almost entirely. In this process, the original minaret became a victim. ${ }^{83}$

An unexpected deviation from the plan of 1973 is the fact that the prayer niche or mihrab is not central in the qibla wall (front wall of the mosque, right-angled over the qibla or

79 D.H. Varley \& H.M. Matthew (eds.), The Cape Journals of archdeacon Merriman 1848-1855, p. 28.

80 The madrasa was erected after 1868. In his will, Jabar El-din provided for the congregation to erect a school on the site at their own cost. Congregation is indicated wrongly as municipality in the translated version of the will in the possession of the mosque. The aerial photograph, Surveys and Mapping, Job no. 141, Strip no. 50A, Photograph 23939, 1939, shows the madrasa completed.

81 Personal communication, Imam A. Sirkhotte, 2007-02-16.

82 The minbar for the recital of the khutba is currently in the northern corner of the mosque.

83 The mosque falls within the area declared as white group area on 20 October 1967, in terms of proclamation 269. Deeds Office, Erf 2899, Uitenhage. 
prayer direction). According to one of the available photographs, it had indeed been in the centre of the original wall. This could be a mistake by a negligent draughtsman, or it may be that it was considered to move the mihrab to be more central to the enlarged space. However, this move is not indicated on the plan or in the mosque. The central position in the original mosque is above suspicion.

On the plan, the building was almost a square, $9600 \times 10100$, plastered and under a simple hipped roof with finials on the ridge ends. On the side facing Cuyler Street there was an open veranda that might have been situated slightly back from the side walls, but stretched along the full width of the building. Here the photographs present contradictory evidence. Photograph 1, which should be regarded as the older of the two and dates from c 1935, vaguely shows a small onion dome on a circular drum (Figure 1); the other photograph (exact date unknown but later, on account of the size of the trees of which the shade is absent from photograph 1), ${ }^{84}$ a wider veranda than that which the plan reveals. (Figure 2)

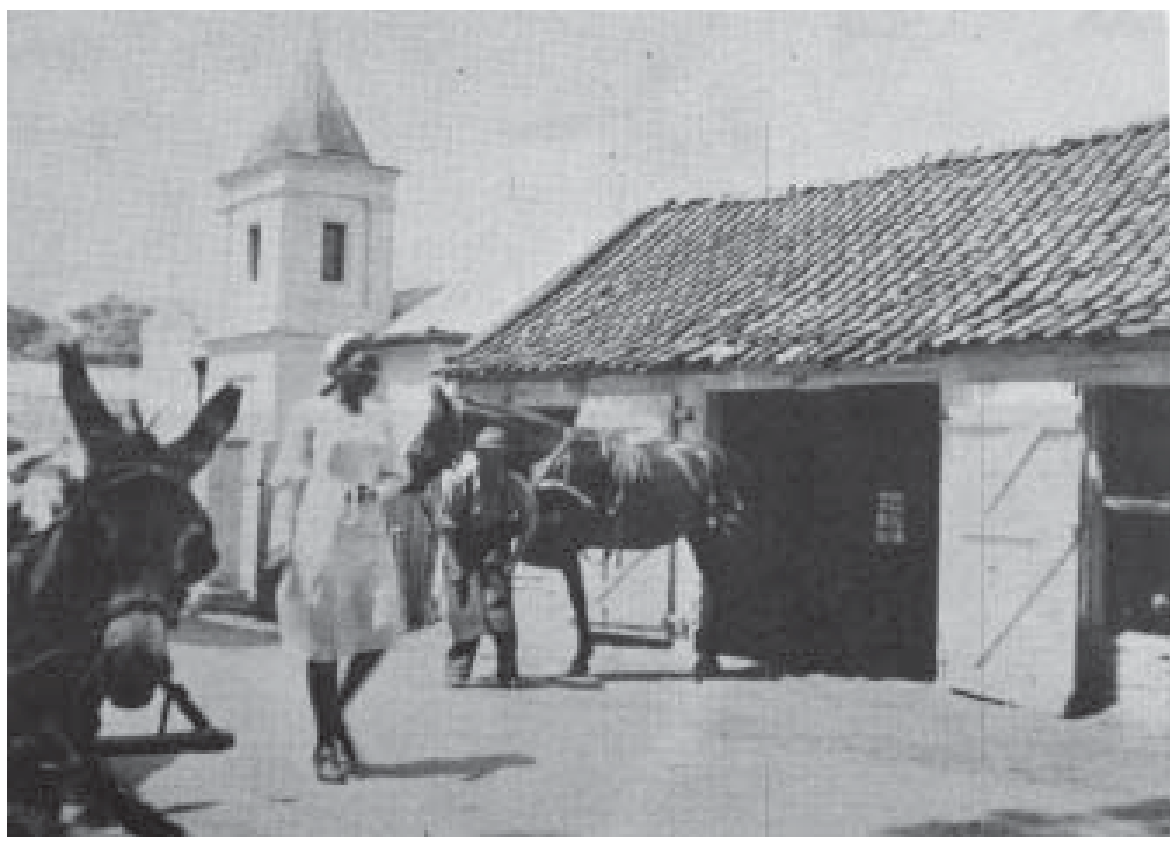

Figure 1. The mosque photographed from Caledon street in c 1935

84 Photographs: A.G. Abrahams (ed.), Muslim heritage and ancestry Port Elizabeth and Uitenhage, s.p. All statements in this section of the article that are recorded without reference are based on personal and telephonic interviews with Imam A. Sirkhotte, 2006-12-15; 2007-02-16. He remembers that the street wall was built in the 1950s, but it must have been done at an earlier date. An aerial photograph of 1939 shows the wall 


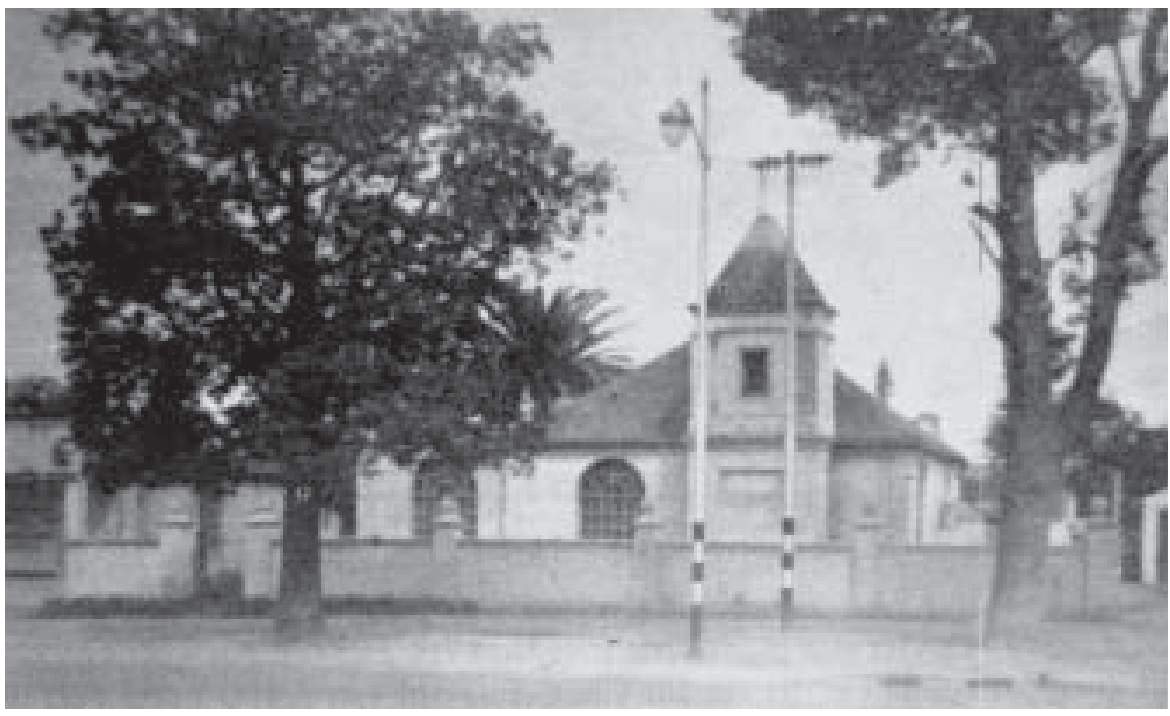

Figure 2. The mosque photographed from Caledon Street c 1955

Could this be the dome to which Merriman referred? And was there only one on the street corner? The variety of minarets with crescents he recorded is easier to explain. From the plans, it is clear that there was only one fully fledged minaret, but there were indeed two prominent ridge finials on the roof and another point on the little dome. According to Merriman, they were gilded. Should this photographic evidence and Merriman's remark refer to the same dome, it would also be the first in South Africa. ${ }^{85}$

The minaret was a sturdy square structure of plasterwork and corbel moulding in three storeys. Plastered corner columns on the first floor supported the upper floor on simple capitals. This floor comprised a podium base on which the tower roof (octagonal on the first photograph, square on the later photograph) rested. Inside, there was a wooden staircase and windows to all four sides allowed the Muezzin to call the faithful to prayers.

completed and the trees along the street to be newly planted: Surveys and Mapping, 1939, Job no. 141, Strip no. 50A, Photograph 23939. The farrier in the photograph is George Padoa (1870-1955). His age on the photograph is guessed at between 60 and 70, thus the photograph could have been taken in c 1935. CAD: MOOC 6/9/23755, no. 6151/55, Death notice of George Padoa, 1955-10-29. Twenty years later the trees were fully grown: Surveys and Mapping, 1958, Job no. 422, Strip no. 2, Photograph 6295.

The first mosque in Cape Town where a dome on the minaret was used was the Hanafi mosque in Long Street, c 1881. The well-known Turkish "pencil point" appears to have been the first choice and was used on the Shafee and Boorhanol Islam mosques (both c 1884) for their minarets. CAD: E2030, E2137; AG13491. 
Currently, there is a search for more photographs of the mosque to either confirm or refute some decisions about the appearance of the mosque. In the meantime, two preliminary reconstructions, to be regarded as working documents, have been prepared (Figure 3).

The appearance of the mosque is surprising. The first free-standing mosques in the Cape were all of the hall church type and the first mosques to deviate from this typology were the Hanafi mosque in Long Street, c 1881, and the Masjied Boorhanol Islam, c 1884, although the hall type was still used for various mosques after these. Almost forty years before the erection of these two mosques, a building was constructed in Uitenhage which differed radically from the development of the mosque pattern in Cape Town. It was a certain design that did not revert to the shape of church buildings in the vicinity, but that immediately established a clear typology of its own.

Certain building influences do indeed appear to be local. The plasterwork and horizontal moulding at storey and roof levels are widespread in the Eastern Cape in what is referred to as the Late Georgian Period (1820-1837) by Ronald Lewcock. ${ }^{86}$ The hipped roof was also a common shape for free-standing buildings. The rectory of the Dutch Reformed Church, constructed slightly later than the mosque, had a similar roof. ${ }^{87}$

By this time, thatched roofs had lost their popularity and they were replaced by shingle roofs (made of the wood of the coral tree, Erythrina caffra), Welsh (and sometimes local) slate and fired roof tiles. ${ }^{88}$ After 1825 , the tiles could also have been manufactured locally in Uitenhage. ${ }^{89}$ Consequently, the galvanised corrugated iron roof on the photographs had to represent a further change in the history of the building. This material came into general use only in the 1860 s and 1870 s.

The minaret itself might have been influenced by the tower of the Dutch Reformed church. Its placement as part of the external wall and the corbel mouldings, of which the first is at roof level, show strong similarities with the church tower. Even the octagonal tower roof might have repeated that of the church. However, entry could not be through the minaret because it served another purpose. The most significant characteristic that distinguishes it from other buildings was the deeply extended niche and the crescents on gilded "minarets" as related by Merriman.

R. Lewcock, Early nineteenth century architecture in South Africa (Cape Town, 1963), pp. 301-302.

O. Terblanche (ed.), Uitenhage the golden town, p. 32.

In 1834 C.G. Holl applied on behalf of the Civil Commissioner of Uitenhage to pull down the gable and to replace the thatched roof of the Public Offices with tiles. CAD: C.O. 2748, no. 83/91, 1834-07-04.

89 R. Lewcock, Early nineteenth century architecture in South Africa, pp. 228-229. 

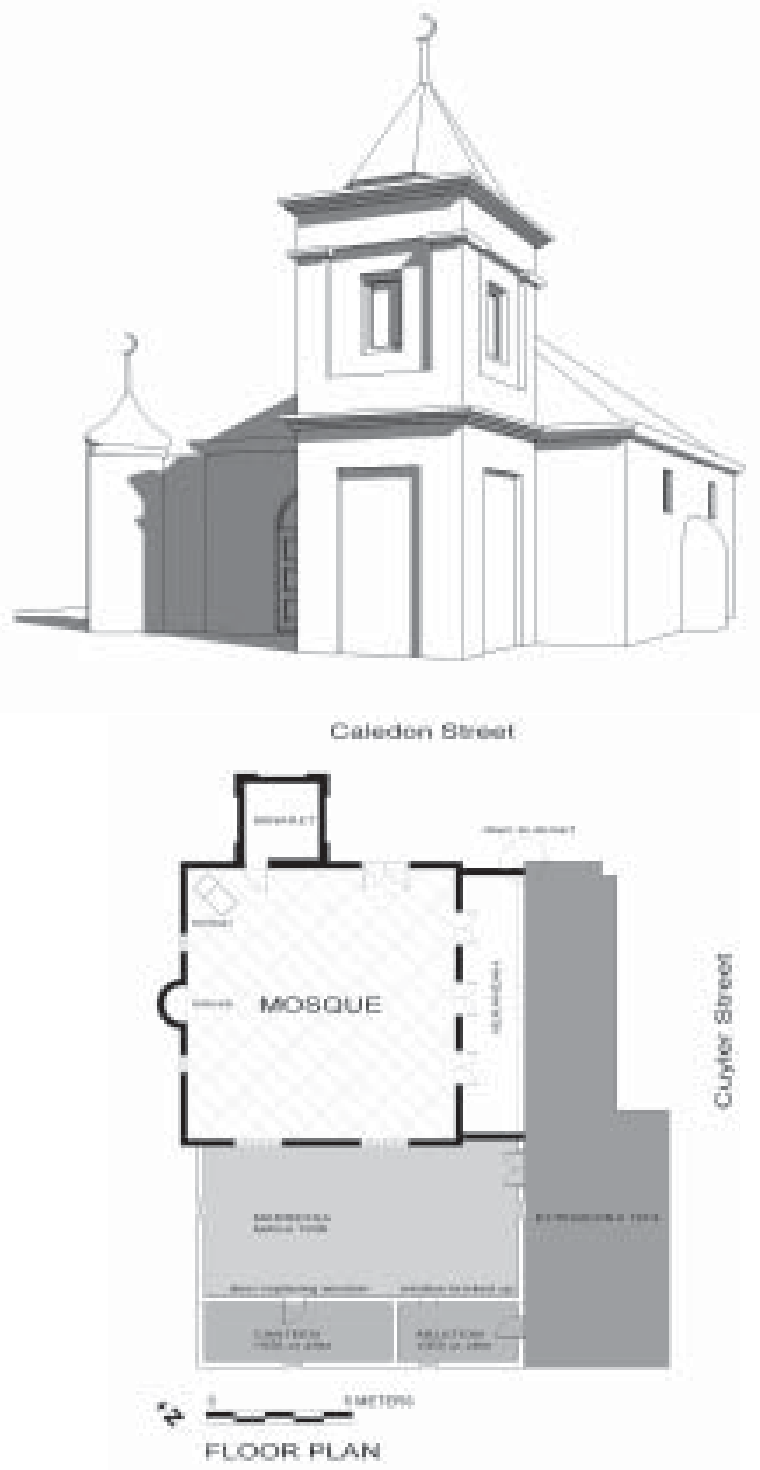

Figure 3. Reconstructed plan and appearance of the first mosque. Drawings by Hannes Jacobs. 


\section{Conclusion}

The field lies fallow as regards research on the history of Islam in the Eastern Cape, despite the fact that Muslims had inhabited the area and practised their faith there even before the arrival of the British settlers. The limited sources are repetitive and often mutually selfreferenced.

The oral traditions have been preserved carefully in the communities and, in the absence of written history, they provide the point of departure for research. The traditions can be tested by means of archival sources. Mosques and cemeteries provide further physical texts that can be read together with plans and photographs.

Despite the fact that the founders of Islam in Uitenhage have been identified and that it might be possible to recreate the image of the mosque erected there, many questions remain unanswered.

Who was Jan Berdien or Jabar El-din really and from where did his family come? Tradition would have it that it is from Macassar and that they stood strong in the faith. Could the design of the mosque point to an architectural source and thus throw any light on his place of origin? This is a most tempting possibility, but at this point will have to be purely speculative. What was the reason why Jabar El-din went to Uitenhage? Although he dominates the traditions, it is necessary to determine which other families played founding and leading roles. Here his will might be used as point of departure, thus also the life and actions of Fortuin Weis in Port Elizabeth. The necessity for oral history is enhanced by Weis's reputation. The name or significance of no other Muslim has been recorded in travel journals, diaries or historical writings of the Eastern Cape. Finally, it is necessary to record further oral recollections and to collect visual material and to index it - something that has been started at the South End museum in Port Elizabeth.

Oral history is crucial for researchers in this field. Often it is the only source from which a search can be started. 